[Article]

\title{
多种类杂环化合物的药理和毒理活性系数构效关系
}

\author{
朱志臣 ${ }^{1} \quad$ 王 强 ${ }^{2, *} \quad$ 贾青竹 $^{3} \quad$ 夏淑倩 ${ }^{4}$ 马沛生 ${ }^{4}$ \\ ('天津城建大学理学院, 天津 300384; 2 天津科技大学材料科学与化学工程学院, 天津 300457 ; \\ ${ }^{3}$ 天津科技大学海洋科学与工程学院, 天津 $300457 ;{ }^{4}$ 天津大学化工学院, 天津 300072)
}

\begin{abstract}
摘要：杂环类化合物在卫生保健和药物分子设计领域发挥关键作用, 在西药中占有重要地位. 本工作针对扩 展距离矩阵提出了一组范数指数, 基于扩展距离矩阵的范数指数构建了一个新的构效关系模型, 并对杂环类化 合物二苯并呋喃的芳烃受体亲和性 $\left(\mathrm{pEC} \mathrm{C}_{50}\right)$ 以及芳香和杂环芳香胺的诱导有机体变异力 $(\mathrm{In} R)$ 进行了计算预测. 结果表明, 基于扩展距离矩阵范数指数建立的构效关系模型可以很好地预测 $\mathrm{pEC} \mathrm{C}_{50}$ 和 $\mathrm{In} R$. 其中, $\mathrm{pEC}$ 预测结 果的平均绝对误差 (AAD)为 0.403 , 相关性系数 $r^{2}=0.876, \ln R$ 预测结果的 $A A D$ 为 $0.702, r^{2}=0.779$. 与其他预测 方法的对比结果表明, 本工作不仅能够利用一个完全相同的数学表达模型同时对 $\mathrm{pEC}$ 和 $\ln R$ 进行预测, 而且 预测结果在准确性和稳定性上都有显著改善.
\end{abstract}

关键词：二苯并呋喃；芳香和杂环芳香胺；芳烃受体亲和性；诱导有机体变异力；构效关系； 范数指数; 预测

中图分类号: 0641

\section{Structure-Property Relationship for the Pharmacological and Toxicological Activity of Heterocyclic Compounds}

\author{
ZHU Zhi-Chen ${ }^{1} \quad$ WANG Qiang ${ }^{2, *} \quad$ JIA Qing-Zhu ${ }^{3} \quad$ XIA Shu-Qian ${ }^{4} \quad$ MA Pei-Sheng ${ }^{4}$ \\ ('School of Science, Tianjin University of Urban Construction, Tianjin 300384, P. R. China;
}

${ }^{2}$ School of Material Science and Chemical Engineering, Tianjin University of Science and Technology, Tianjin 300457, P. R. China;

${ }^{3}$ School of Marine Science and Engineering, Tianjin University of Science and Technology, Tianjin 300457, P. R. China; ${ }^{4}$ School of Chemical Engineering and Technology, Tianjin University, Tianjin 300072, P. R. China)

\begin{abstract}
Heterocyclic molecules play a crucial role in health care and in pharmaceutical drug design. A large number of drugs used in Western medical practice are heterocyclic molecules. In this study, a set of norm indexes of the extended distance matrix are proposed. From these a stable and accurate structureproperty relationship model was developed for the prediction of the aryl hydrocarbon receptor binding affinity $\left(\mathrm{pEC}_{50}\right)$ of dibenzofurans and the mutagenic potency $(\ln R)$ of aromatic and heteroaromatic amines. Our results indicate that the new model, based on these norm indexes, provides very satisfactory results, and that the average absolute differences for $\mathrm{pEC}_{50}$ prediction and $\operatorname{In} R$ prediction were 0.403 and 0.702 with $r^{2}$ (square correlation coefficient) values of 0.876 and 0.779 , respectively. A comparison of these results with other methods demonstrates that our method, based only on the same mathematical model, performed better in terms of both accuracy and stability.
\end{abstract}

Key Words: Dibenzofuran; Aromatic and heteroaromatic amine; Aryl hydrocarbon receptor affinity; Mutagenic potency; Structure-property relationship; Norm index; Prediction

Received: January 14, 2014; Revised: April 16, 2014; Published on Web: April 16, 2014.

"Corresponding author. Email: wang_q@tust.edu.cn; Tel: +86-22-58088631,+86-13652089933.

The project was supported by the National Natural Science Foundation of China (21306137, U1162104).

国家自然科学基金(21306137, U1162104)资助项目

(c) Editorial office of Acta Physico-Chimica Sinica 


\section{Introduction}

Heterocyclic compounds are important as drugs. According to Hammond, ${ }^{1}$ the most important objective of synthesis is not production of new compounds, but production of properties. And for the drug discovery process, the aim is at bringing to market new drugs with desirable pharmaco-dynamicity, and favorable ADMET (Absorption, Distribution, Metabolism, Elimination, and Toxicity) properties. ${ }^{2-5}$ Therefore, drug designers and toxicologists pay much attention to the beneficial and deleterious effects of heterocyclic moieties in molecules.

In view of the fact that most potential therapeutic agents and the majority of known drugs do not have experimental data available for their evaluation, theoretical calculations are very useful in the initial screening of compound libraries. Previous studies have demonstrated that quantitative structure-activity/ property relationships (QSAR/QSPR) approach is successful in predicting activities, properties, and toxicities including mutagenicity (described as $\ln R$ ) of aromatic and hetero-aromatic amines. ${ }^{6-12}$ For example, the aryl hydrocarbon receptor binding affinity (described as $\mathrm{pEC}_{50}$ ) is well documented in the field of toxicology for organics. ${ }^{13-15}$ Basak et al. ${ }^{16}$ proposed a hierarchical quantitative structure-activity relationship (HiQSAR) approach for the $\mathrm{pEC}_{50}$ prediction. According to their investigation, the topostructural (TS) and topochemical (TC) descriptors could provide a good model for the $\mathrm{pEC}_{50}$ prediction with a $r^{2}$ value of 0.852 . And with Basak et al.'s method, the $r^{2}$ value is of 0.748 for $\ln R$ prediction. ${ }^{17}$ In order to explore the binding mode and interaction mechanism between hydroxylated polychlorinated biphenyls and aryl hydrocarbon receptor, Cao et $a l{ }^{18}$ proposed some comparative molecular similarity index analysis models by using molecular dynamics simulations. And their optimum 3D-QSAR model could show good predictive ability $\left(r^{2}=0.913\right)$ and good mechanism interpretability.

Recently, a universal positional distributive contribution theory for the prediction of various properties of organic compounds was developed. ${ }^{19-21}$ In this theory, the specific position of a group in the molecule was considered as the position factor. Here, the position factor was used to take into account longer distance interactions, which could distinguish the overall isomer including cis- and trans- or Z- and $E$-structures of organic compounds for their thermodynamics properties. Moreover, our previous works suggest that it is possible to use a totally same universal framework to predict the critical properties and the thermodynamics properties of organic compounds containing various functionalities.

Very recently, a topological index was proposed based on atom characters (e.g., atom radius and atom electronegativity etc.) by our research group, which has been successfully used for predicting the critical micelle concentration (CMC) of various surfactants, ${ }^{22}$ the decomposition temperature, ${ }^{23}$ toxicity of ionic liquids, ${ }^{24}$ and the aquatic toxicity for various narcotic pollutants. ${ }^{25}$ And, it is logical to see if this topological index could be used for prediction of pharmacological and toxicological ac- tivities of drugs.

In this work, based on this topological index and through data mining, a universal model has been developed for prediction of the two different properties. The major objectives of this study are: (i) to propose a set of norm indexes, (ii) to establish a more general QSPR model for prediction of pharmacological and toxicological activities of heterocyclic compounds, and (iii) to compare the performance of our model with other methods.

\section{Methodology}

\subsection{Pharmacological and toxicological activity data}

\subsubsection{Aryl hydrocarbon $(\mathrm{AH})$ receptor data}

In this work, a set of 32 dibenzofurans compounds (structure shown as in Fig.1) with $\mathrm{AH}$ receptor binding potency values obtained from the literature ${ }^{26}$ were used for QSAR model development, and the experimental data are listed in Table S1 (shown as Supporting Information).

\subsubsection{Mutagenicity of aromatic and heteroaromatic amines}

The set of 95 aromatic and heteroaromatic amines used to study mutagenic potency (described as $\ln R$ ) was obtained from Debnath et al., ${ }^{27}$ and their experimental mutation rates are listed in Table S2 (shown as Supporting Information).

\subsection{Proposed method}

In our previous work, ${ }^{22}$ the extended adjacency matrix $\boldsymbol{M}_{\mathrm{A}}$, the extended interval matrix $\boldsymbol{M}_{\mathrm{B}}$, the extended interval jump matrix $\boldsymbol{M}_{\mathrm{C}}$, and extended distance matrix $\boldsymbol{M}_{\mathrm{D}}$ are defined, respectively.

$$
\boldsymbol{M}_{\mathrm{A}}=\left[\begin{array}{l}
\boldsymbol{M}_{\mathrm{a}} \\
\boldsymbol{M}_{\mathrm{e}}
\end{array}\right] ; \quad \boldsymbol{M}_{\mathrm{B}}=\left[\begin{array}{l}
\boldsymbol{M}_{\mathrm{b}} \\
\boldsymbol{M}_{\mathrm{e}}
\end{array}\right] ; \quad \boldsymbol{M}_{\mathrm{C}}=\left[\begin{array}{c}
\boldsymbol{M}_{\mathrm{c}} \\
\boldsymbol{M}_{\mathrm{e}}
\end{array}\right] ; \quad \boldsymbol{M}_{\mathrm{D}}=\left[\begin{array}{c}
\boldsymbol{M}_{\mathrm{d}} \\
\boldsymbol{M}_{\mathrm{e}}
\end{array}\right]
$$

The constituents of the distance matrix $\boldsymbol{M}_{\mathrm{d}}$ and the extended matrix, $\boldsymbol{M}_{\mathrm{e}}$, are described as follows.

$$
\begin{aligned}
& \boldsymbol{M}_{\mathrm{a}}=\left(a_{i j}\right), \quad a_{i j}=\left\{\begin{array}{l}
1 \text { (if } i \text { and } j \text { are adjacent) } \\
0 \text { (otherwise) }
\end{array}\right. \\
& \boldsymbol{M}_{\mathrm{b}}=\left(a_{i j}\right), \quad a_{i j}=\left\{\begin{array}{l}
2 \text { (if the path length between } i \text { and } j \text { is } 2) \\
0 \text { (otherwise) }
\end{array}\right. \\
& \boldsymbol{M}_{\mathrm{c}}=\left(a_{i j}\right), \quad a_{i j}= \begin{cases}3 \text { (if the path length between } i \text { and } j \text { is } 3) \\
0 \text { (otherwise) }\end{cases} \\
& \boldsymbol{M}_{\mathrm{d}}=\left(a_{i j}\right), \text { distance matrix } a_{i j}=n
\end{aligned}
$$

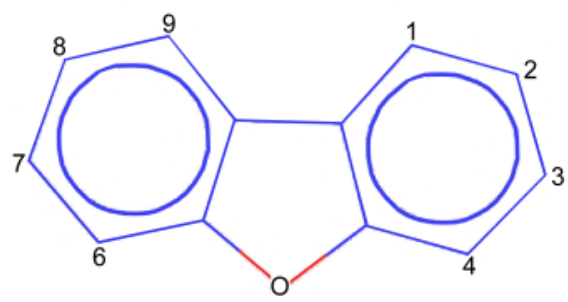

Fig.1 Structure for the dibenzofuran data set provided in Table $\mathrm{S} 1$ 


$$
\boldsymbol{M}_{\mathrm{e}}=\left[\begin{array}{l}
\text { eletronegativity fraction } \\
\text { van der Waals radius } \\
\text { the minimum bond length with adjacent } \\
\text { atom except hydrogen } \\
\text { the number of adjacent atom except hydrogen } \\
\text { the number of adjacent hydrogen atom }
\end{array}\right]
$$

Here, as for $\boldsymbol{M}_{\mathrm{A}}, \boldsymbol{M}_{\mathrm{B}}, \boldsymbol{M}_{\mathrm{C}}$, and $\boldsymbol{M}_{\mathrm{D}}$, a set of norm indexes have been proposed as follows.

$$
\begin{aligned}
\boldsymbol{M}_{\mathrm{A}}^{\prime}= & a_{\mathrm{a} 1} \operatorname{norm}\left(\boldsymbol{M}_{\mathrm{A}}, 1\right)+a_{\mathrm{a} 2} \operatorname{norm}\left(\boldsymbol{M}_{\mathrm{A}}, 2\right)+a_{\mathrm{a} 3} \operatorname{norm}\left(\boldsymbol{M}_{\mathrm{A}}, \text { fro }\right)+ \\
& a_{\mathrm{a} 4} \operatorname{norm}\left(\boldsymbol{M}_{\mathrm{A}}, \inf \right) \\
\boldsymbol{M}_{\mathrm{B}}^{\prime}= & a_{\mathrm{b} 1} \operatorname{norm}\left(\boldsymbol{M}_{\mathrm{B}}, 1\right)+a_{\mathrm{b} 2} \operatorname{norm}\left(\boldsymbol{M}_{\mathrm{B}}, 2\right)+a_{\mathrm{b} 3} \operatorname{norm}\left(\boldsymbol{M}_{\mathrm{B}}, \text { fro }\right) \\
\boldsymbol{M}_{\mathrm{C}}^{\prime}= & a_{\mathrm{c} 1} \operatorname{norm}\left(\boldsymbol{M}_{\mathrm{C}}, 1\right)+a_{\mathrm{c} 2} \operatorname{norm}\left(\boldsymbol{M}_{\mathrm{C}}, 2\right)+a_{\mathrm{c} 3} \operatorname{norm}\left(\boldsymbol{M}_{\mathrm{C}}, \text { fro }\right) \\
\boldsymbol{M}_{\mathrm{D}}^{\prime}= & a_{\mathrm{d} 1} \operatorname{norm}\left(\boldsymbol{M}_{\mathrm{D}}, 1\right)+a_{\mathrm{d} 2} \operatorname{norm}\left(\boldsymbol{M}_{\mathrm{D}}, 2\right)+a_{\mathrm{d} 3} \operatorname{norm}\left(\boldsymbol{M}_{\mathrm{D}}, \text { fro }\right)+ \\
& a_{\mathrm{d} 4} \operatorname{norm}\left(\boldsymbol{M}_{\mathrm{D}}, \text { inf }\right)
\end{aligned}
$$

where $\operatorname{norm}\left(\boldsymbol{M}_{\mathrm{A}}, 1\right)$ means the largest column sum of matrix $\boldsymbol{M}_{\mathrm{A}}, \operatorname{norm}\left(\boldsymbol{M}_{\mathrm{A}}, 2\right)$ means the largest singular value of matrix $\boldsymbol{M}_{\mathrm{A}}, \operatorname{norm}\left(\boldsymbol{M}_{\mathrm{A}}\right.$, fro $)$ is the frobenius- norm of matrix $\boldsymbol{M}_{\mathrm{A}}$, and $\operatorname{norm}\left(\boldsymbol{M}_{\mathrm{A}}\right.$, inf) is the infinite-norm of matrix $\boldsymbol{M}_{\mathrm{A}}$.

Using these norm indexes, two QSPR models for $\mathrm{pEC}_{50}$ and $\ln R$ prediction are expressed as Eq.(1) and Eq.(2). The modeling work is performed with ordinary least squares regression.

$$
\begin{gathered}
\mathrm{pEC}_{50}=\boldsymbol{M}_{\mathrm{A}}^{\prime}+\boldsymbol{M}_{\mathrm{B}}^{\prime}+\boldsymbol{M}_{\mathrm{C}}^{\prime}+\boldsymbol{M}_{\mathrm{D}}^{\prime}+b_{1} \exp (1 / N)+ \\
b_{2} \exp \left(1 / M_{\mathrm{W}}\right)+M_{0} \\
\ln R=\boldsymbol{M}_{\mathrm{A}}^{\prime}+\boldsymbol{M}_{\mathrm{B}}^{\prime}+\boldsymbol{M}_{\mathrm{C}}^{\prime}+\boldsymbol{M}_{\mathrm{D}}^{\prime}+b_{1} \exp (1 / N)+ \\
b_{2} \exp \left(1 / M_{\mathrm{W}}\right)+M_{0}
\end{gathered}
$$

\begin{tabular}{|c|c|c|c|}
\hline \multicolumn{2}{|c|}{ Parameters } & \multirow{2}{*}{$\begin{array}{c}\mathrm{pEC}_{50} \\
-22.7744\end{array}$} & \multirow{2}{*}{$\begin{array}{c}\ln R \\
-0.3525\end{array}$} \\
\hline$M_{\text {A }}$ & $a_{\mathrm{a} 1}$ & & \\
\hline & $a_{\mathrm{a} 2}$ & -48.5409 & 29.6775 \\
\hline & $a_{33}$ & -462.3183 & -13.7446 \\
\hline & $a_{24}$ & -5.9163 & 0.4876 \\
\hline \multirow[t]{3}{*}{$\boldsymbol{M}_{\mathrm{B}}$} & $a_{\mathrm{b} 1}$ & -0.1887 & -0.0163 \\
\hline & $a_{\mathrm{b} 2}$ & 156.6532 & -19.0118 \\
\hline & $a_{63}$ & 428.6100 & 10.4300 \\
\hline \multirow[t]{3}{*}{$\boldsymbol{M}_{\mathrm{C}}$} & $a_{\mathrm{cl}}$ & 0.2801 & -0.0005 \\
\hline & $a_{\mathrm{c} 2}$ & -55.6900 & -10.7641 \\
\hline & $a_{\mathrm{c} 3}$ & 16.3321 & 4.3405 \\
\hline \multirow[t]{4}{*}{$\boldsymbol{M}_{\mathrm{D}}$} & $a_{\mathrm{d} 1}$ & 0.2730 & 0.2099 \\
\hline & $a_{\mathrm{d} 2}$ & -18.5465 & -1.1891 \\
\hline & $a_{\mathrm{d} 3}$ & 14.0124 & 0.6848 \\
\hline & $a_{\mathrm{s} 4}$ & -0.1447 & -0.0874 \\
\hline \multicolumn{2}{|c|}{$b_{1}$} & 3544.4709 & 53.2849 \\
\hline \multicolumn{2}{|c|}{$b_{2}$} & 10679.1349 & -274.4253 \\
\hline \multicolumn{2}{|c|}{$M_{0}$} & -14604.7935 & 205.8309 \\
\hline
\end{tabular}

Here, $N$ for total number of atoms, $M_{\mathrm{w}}$ is molecular weight, $M_{0}$ is the constant added. As for parameters $a, b_{1}, b_{2}$, and $M_{0}$, the regression results for prediction of $\mathrm{pEC}_{50}$ and $\ln R$ are summarized in Table 1.

Some statistical metrics for our predictive models are as follows. PRESS stands for the predicted sum of squared error, AD stands for the absolute difference, RD means relative deviation, and $\mathrm{AAD}$ is the average absolute difference.

Table 1 Parameters for prediction of $\mathrm{pEC}_{50}$ and $\ln R$

$$
\begin{aligned}
& \text { PRESS }=\sum_{i=1}^{n}\left(\mathrm{pEC}_{50, i, \text { expt. }}-\mathrm{pEC}_{50, i, \text { pred. }}\right)^{2} \\
& \mathrm{SS}_{\text {Total }}=\sum_{i=1}^{n}\left(\mathrm{pEC}_{50, i, \text { expt. }}-\sum\left(\mathrm{pEC}_{50, i, \text { expt. }} / N\right)^{2}\right. \\
& r^{2}=1-\frac{\text { PRESS }}{\mathrm{SS}_{\text {Total }}} \\
& \mathrm{AD}=\left|\mathrm{pEC}_{50, i, \text { expt. }}-\mathrm{pEC}_{50, i, \mathrm{pred} .}\right| \\
& \mathrm{RD}=\left|\frac{\mathrm{pEC}_{50, i, \text { expt. }}-\mathrm{pEC}_{50, i, \mathrm{pred}}}{\mathrm{pEC}_{50, i, \text { expt. }}}\right| \times 100 \% \\
& \mathrm{AAD}=\frac{1}{N} \sum_{i=1}^{N}\left|\frac{\mathrm{pEC}_{50, i, \text { expt. }}-\mathrm{pEC}_{50, i, \mathrm{pred}} .}{\mathrm{pEC}_{50, i, \text { expt. }}}\right| \times 100 \%
\end{aligned}
$$

\section{Results and discussions}

\section{$3.1 \mathrm{pEC}_{50}$ prediction results}

The $\mathrm{pEC}_{50}$ prediction results are provided in Table $\mathrm{S} 1$ (shown as Supporting Information), along with the differences between the experimental and predicted values. The calculated by model Eq.(1) vs experimental $\mathrm{pEC}_{50}$ scatter plot for this regression is presented in Fig.2(a). And statistical metrics for the predictive model are listed in Table 2. The results in Fig.2(a) indicate that the predicted $\mathrm{pEC}_{50}$ agree well with the "experimental results". The AAD for $\mathrm{pEC}_{50}$ prediction of 32 dibenzofurans compounds is 0.403 . Also, our high-quality prediction model is evidenced by a $r^{2}$ value of 0.876 and a PRESS value of 7.734 .

\section{$3.2 \ln R$ prediction results}

The $\ln R$ prediction results are provided in Table S2, Table 2, and Fig.2(b). Results indicate that our new model Eq.(2) for predicting $\ln R$ has good overall accuracy. The AAD for $\ln R$ prediction of 95 aromatic and heteroaromatic amines is 0.702 , the $r^{2}$ value is 0.779 , and the PRESS value is 80.3 .

\subsection{Comparison with the HiQSAR approach}

The $\mathrm{pEC}_{50}$ prediction results with the HiQSAR approach proposed by Basak et al. ${ }^{16}$ had been used for comparison, and the comparison results are also provided in Table S1 and Table 2. According to Basak et al., ${ }^{16}$ the topostructural (TS) and topochemical (TC) descriptors could provide a good model for the $\mathrm{pEC}_{50}$ prediction with a $r^{2}$ value of 0.852 . Using their method, the AAD for $\mathrm{pEC}_{50}$ prediction is 0.452 , and the PRESS value is 9.270. In addition, with the method of Basak et al., ${ }^{17}$ the AAD for $\ln R$ prediction is 0.747 , the $r^{2}$ value is of 0.748 , and the PRESS value is 87.6. Comparison results therefore indicate that obvious improvement could be obtained with our method.

In Basak et al.'s research, prediction for $\mathrm{pEC}_{50}$ and $\ln R$ of organic compounds was based on about 72 or even more optimal descriptors which had been selected from 300 descriptors. Moreover, in their work, the number of descriptors is large with respect to the number of chemical compounds in the data set, so the ordinary least-square regression is inappropriate.

While, in our work, based on the extended distance matrix, a set of norm indexes have been proposed. By using these norm indexes, the structure and the composition of molecules could be determined stably, accurately, and completely, and also, the isomers could be distinguished well. Moreover, it should be 

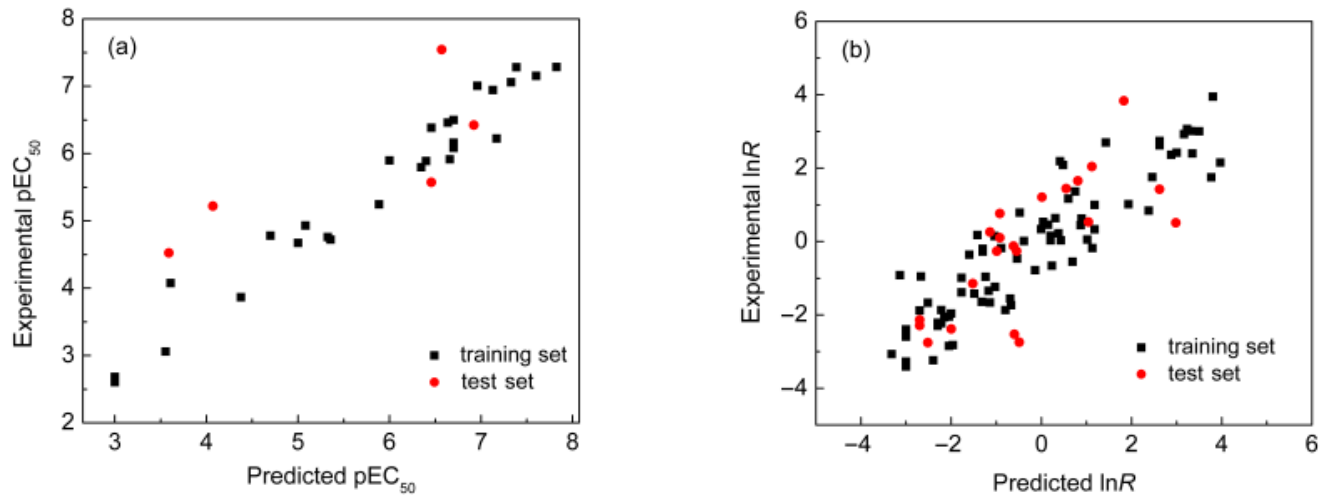

Fig.2 Scatter plot showing the correlation between predicted by our models and experimental $\mathbf{p E C}_{50}$ (a) and $\ln R$ (b)

Table 2 Regression results for prediction of $\mathrm{pEC}_{50}$ and $\ln R$ based on our models and Basak et al.'s method

\begin{tabular}{|c|c|c|c|c|}
\hline & \multicolumn{2}{|c|}{$\mathrm{pEC}_{50}$} & \multicolumn{2}{|c|}{$\ln R$} \\
\hline & Basak et al.'s method ${ }^{16}$ & our model & Basak et al.'s method ${ }^{17}$ & our model \\
\hline$r^{2}$ & 0.852 & 0.876 & 0.748 & 0.779 \\
\hline PRESS & 9.270 & 7.734 & 87.6 & 80.3 \\
\hline $\mathrm{AAD}$ & 0.452 & 0.403 & 0.747 & 0.702 \\
\hline
\end{tabular}

strongly stated that firstly, only 17 indices are considered for property prediction of chemical compounds, among which 14 indices are deduced from these norm indexes. Secondly and more importantly, a totally same mathematical model is developed for predicting $\mathrm{pEC}_{50}$ and $\ln R$ of organic compounds containing various functionalities with better prediction performance.

Therefore, it could be demonstrated that our method with these norm indexes could result in significant improvement both in accuracy and generality for predicting $\mathrm{pEC}_{50}$ and $\ln R$. Also, owing to the much less variables considered, this algorithm could perform well in the ductility, which is very important and particularly valuable for a prediction method.

\subsection{Leave-one-out cross-validation}

In this work, the leave-one-out algorithm was used for the validation of the prediction of our QSPR models, and results are also shown in Table 3. Results show that the $r^{2}$ and PRESS are acceptable and they are as good as the results calculated by Eq.(1) and Eq.(2). The calculated values by leave-one-out crossvalidation demonstrate that our QSPR models Eq.(1) and Eq. (2) based on these norm indexes have good predictive stability and reliability for predicting the $\mathrm{pEC}_{50}$ and $\ln R$.

Table 3 Regression results for prediction of $\mathrm{pEC}_{50}$ and $\ln R$ based on our model and predicting ability test by leave-one-out cross-validation

\begin{tabular}{llccc}
\hline & \multicolumn{1}{c}{ Method } & Sample number & PRESS & $r^{2}$ \\
\hline $\mathrm{pEC}_{50}$ & model Eq.(1) in this work & 32 & 7.734 & 0.876 \\
& leave-one-out cross-validation & 32 & 7.932 & 0.865 \\
& this work for training set & 27 & & 0.899 \\
$\ln R$ & model Eq.(2) in this work & 95 & 80.306 & 0.779 \\
& leave-one-out cross-validation & 95 & 82.670 & 0.763 \\
& this work for training set & 74 & & 0.814 \\
\hline
\end{tabular}

\section{Conclusions}

In this work, a set of norm indexes for predicting the AH receptor prediction $\left(\mathrm{pEC}_{50}\right)$ of 32 dibenzofurans and the mutagenic potency $\ln R$ of 95 aromatic and heteroaromatic amines was proposed. Based on these norm index, a totally same mathematical model was developed for predicting $\mathrm{pEC}_{50}$ and $\ln R$ of organic compounds containing various functionalities. Results indicated that $\mathrm{pEC}_{50}$ and $\ln R$ were successfully predicted with a significant degree of confidence. With our method, the AAD values for $\mathrm{pEC}_{50}$ prediction and $\ln R$ prediction are 0.403 and $0.702, r^{2}$ values are of 0.876 and 0.779 , respectively. Also, this research provides better prediction results as compared to the HiQSAR method of Basak et al., despite the fact that lesser descriptors were considered and used in this research as compared to other models. Moreover, our results demonstrated that it is possible to use a totally same mathematical model for predicting $\mathrm{pEC}_{50}$ and $\ln R$ of organic compounds containing various functionalities with better prediction performance.

Acknowledgments: The author would give many thanks to Mr. YAN Fang-You (School of Chemical Engineering and Technology, Tianjin University) who have contributed for valuable advice and discussion, and also, the author wishes to thank Miss SHAHID Kanwal (School of Material Science and Chemical Engineering, Tianjin University of Science and Technology) who has contributed for refining of the English manuscript.

Supporting Information: Experimental and predicted the ar$\mathrm{yl}$ hydrocarbon $(\mathrm{AH})$ receptor binding affinity $\left(\mathrm{pEC}_{50}\right)$ of dibenzofurans and the mutagenic potency $\ln R$ of aromatic and heteroaromatic amines based on this model and Basak et al.'s method, and a detailed procedure for the $\mathrm{pEC}_{50}$ estimation have been included. This information is available free of charge via 
the internet at http: //www.whxb.pku.edu.cn.

\section{References}

(1) Hammond, G. S. Norris Award Lecture, 1968

(2) Michielan, L.; Moro, S. J. Chem. Inf. Model. 2010, 50, 961. doi: $10.1021 / \mathrm{ci} 100072 \mathrm{z}$

(3) Khan, M. T.; Sylte, I. Curr. Drug Discovery Technol. 2007, 4, 141. doi: $10.2174 / 157016307782109706$

(4) Mager, D. E. Adv. Drug Delivery Rev. 2006, 58, 1326. doi: $10.1016 /$ j.addr.2006.08.002

(5) Zhu, H.; Tropsha, A.; Fourches, D.; Varnek, A.; Papa, E.; Gramatica, P.; Oberg, T.; Dao, P.; Cherkasov, A.; Tetko, I. V. J. Chem. Inf. Model. 2008, 48, 766. doi: 10.1021/ci700443v

(6) Basak, S. C.; Mills, D. SAR QSAR Environ. Res. 2001, 12, 481. doi: 10.1080/10629360108039830

(7) Gute, B. D.; Balasubramanian, K.; Geiss, K. T.; Basak, S. C. Environ Toxicol Pharmacol, 2004, 16, 121

(8) Restrepo, G.; Basak, S. C.; Mills, D. Curr. Comput. Aided Drug Des. 2011, 7, 109. doi: 10.2174/157340911795677639

(9) Basak, S. C.; Mills, D. R.; Balaban, A. T.; Gute, B. D. J. Chem. Inf. Comput. Sci. 2001, 41, 671. doi: 10.1021/ci000126f

(10) Godavarthy, S. S.; Robinson, R. L., Jr.; Gasem, K. A. M. Fluid Phase Equilib. 2008, 264, 122. doi: 10.1016/j.fluid.2007.11.003

(11) Basak, S. C.; Mills, D.; Gute, B. D.; Natarajan, R. Top Heterocycl. Chem. 2006, 3, 39.

(12) Li, X. L.; Ye, L.; Wang, X. X.; Wang, X. Z.; Liu, H. L.; Qian, X. P.; Zhu, Y. L.; Yu, H. X. Sci. Total Environ. 2012, 441, 230. doi: 10.1016/j.scitotenv.2012.08.072

(13) Doering, J. A.; Wiseman, S.; Beitel, S. C.; Giesy, J. P.; Hecker, M. Aquat. Toxicol. 2014, 150, 27. doi: 10.1016/j. aquatox.2014.02.009

(14) Gu, C.; Goodarzi, M.; Yang, X.; Bian, Y.; Sun, C.; Jiang, X. Toxicol. Lett. 2012, 208, 269.
(15) Hankinson, O. Arch. Biochem. Biophys. 2005, 433, 379. doi: 10.1016/j.abb.2004.09.031

(16) Basak, S. C.; Mills, D.; Mumtaz, M. M.; Balasubramanian, K. Indian J. Chem. 2003, 42A, 1385.

(17) Basak, S. C.; Mills, D.; Gute, B. D.; Hawkins, D. M. Predicting Mutagenicity of Congeneric and DiverseSets of Chemicals Using Computed Molecular Descriptors: a Hierarchical Approach. In Benigni R(ed) Quantitative Structure-Activity Relationship (QSAR) Models of Mutagens and Carcinogens; CRC: Boca Raton, FL, 2003; pp 207-208.

(18) Cao, F.; Li, X.; Ye, L.; Xie, Y.; Wang, X.; Shi, W.; Qian, X.; Zhu, Y.; Yu, H. Environ. Toxicol. Pharmacol. 2013, 36, 626. doi: 10.1016/j.etap.2013.06.004

(19) Wang, Q.; Ma, P. S.; Jia, Q. Z.; Xia, S. Q. J. Chem. Eng. Data 2008, 53, 1103. doi: 10.1021/je700641j

(20) Wang, Q.; Jia, Q. Z.; Ma, P. S. J. Chem. Eng. Data 2012, 57, 169. doi: $10.1021 /$ je200971z

(21) Jia, Q. Z.; Wang, Q.; Ma, P. S.; Xia, S. Q.; Yan, F. Y.; Tang, H. M. J. Chem. Eng. Data 2012, 57, 3357. doi: 10.1021/je301070f

(22) Zhu, Z. C.; Wang, Q.; Jia, Q. Z.; Tang, H. M.; Ma, P. S. Acta Phys. -Chim. Sin. 2013, 29 (1), 30. [朱志臣, 王 强, 贾青竹, 汤红梅, 马沛生. 物理化学学报, 2013, 29 (1), 30.] doi: 10.3866/PKU.WHXB201210265

(23) Yan, F.; Xia, S.; Wang, Q.; Ma, P. S. J. Chem. Eng. Data 2012, 57, 805. doi: $10.1021 /$ je201023a

(24) Yan, F.; Xia, S.; Wang, Q.; Ma, P. S. J. Chem. Eng. Data 2012, 57, 2252. doi: 10.1021/je3002046

(25) Wang, Q.; Jia, Q. Z.; Yan, L. H.; Ma, P. S.; Xia, S. Q. doi:10.1016/j.chemosphere.2014.02.030

(26) So, S. S.; Karplus, M. J. Med. Chem. 1997, 40, 4360.

(27) Debnath, A. K.; Debnath, G.; Shusterman, A. J.; Hansch, C. A. Environ. Mol. Mutagen. 1992, 19, 37. doi: 10.1002/ em.2850190107 
Supplementary Information for Acta Phys. -Chim. Sin. 2014, 30 (6), 1086-1090 doi: 10.3866/PKU.WHXB201404161

\title{
多种类杂环化合物的药理和毒理活性系数构效关系
}

\author{
朱志臣 ${ }^{1}$ 王 强 ${ }^{2, *} \quad$ 贾青竹 $^{3} \quad$ 夏淑倩 ${ }^{4}$ 马沛生 ${ }^{4}$ \\ ( ${ }^{1}$ 天津城建大学理学院, 天津 $300384 ;{ }^{2}$ 天津科技大学材料科学与化学工程学院, 天津 300457 ; \\ ${ }^{3}$ 天津科技大学海洋科学与工程学院, 天津 $300457 ;{ }^{4}$ 天津大学化工学院, 天津 300072)
}

\section{Structure-Property Relationship for the Pharmacological and Toxicological Activity of Heterocyclic Compounds}

\author{
ZHUZhi-Chen $^{1} \quad$ WANG Qiang $^{2, *} \quad$ JIA Qing-Zhu ${ }^{3} \quad$ XIA Shu-Qian $^{4}$ \\ MA Pei-Sheng4
}

\begin{abstract}
( ${ }^{1}$ School of Science, Tianjin University of Urban Construction, Tianjin 300384, P. R. China;
${ }^{2}$ School of Material Science and Chemical Engineering, Tianjin University of Science and Technology, Tianjin

300457, P. R. China; ${ }^{3}$ School of Marine Science and Engineering, Tianjin University of Science and Technology,

Tianjin 300457, P. R. China; ${ }^{4}$ School of Chemical Engineering and Technology, Tianjin University, Tianjin 300072, P. R. China)
\end{abstract}

*Corresponding author. Email: wang_q@tust.edu.cn; Tel: +86-22-58088631, +86-13652089933. 
Table S1 Experimental and predicted $\mathrm{AH}$ receptor binding affinity $\mathrm{pEC}_{50}$ based on our model eq. (1) and Basak et al.' method, for the set of 32 dibenzofurans compounds

\begin{tabular}{|c|c|c|c|c|c|}
\hline \multirow[t]{2}{*}{ Chemical } & \multirow[t]{2}{*}{ exp. $\mathrm{pEC}_{50}^{26}$} & \multicolumn{2}{|c|}{ Basak et al.' Method ${ }^{16}$} & \multicolumn{2}{|c|}{ This work } \\
\hline & & pred. pEC $\mathrm{p}_{50}$ & $\mathrm{AD}^{\mathrm{a}}$ & pred. pEC 50 & $\mathrm{AD}$ \\
\hline 2-Cl & 3.553 & 3.169 & 0.384 & 3.665 & 0.112 \\
\hline 3-Cl & 4.377 & 4.199 & 0.178 & 4.506 & 0.129 \\
\hline 4-Cl & 3.000 & 3.692 & -0.692 & 3.270 & 0.270 \\
\hline 2,3-diCl & 5.326 & 4.964 & 0.362 & 5.346 & 0.020 \\
\hline 2,6-diCl & 3.609 & 4.279 & -0.67 & 4.958 & 1.349 \\
\hline 2,8-diCl ${ }^{b}$ & 3.590 & 4.251 & -0.661 & 4.128 & 0.538 \\
\hline 1,2,7-trCl & 6.347 & 5.646 & 0.701 & 6.436 & 0.089 \\
\hline 1,3,6-trCl & 5.357 & 4.705 & 0.652 & 5.265 & 0.093 \\
\hline $1,3,8-\operatorname{trCl}^{\mathrm{b}}$ & 4.071 & 5.330 & -1.259 & 4.806 & 0.735 \\
\hline 2,3,8-trCl & 6.000 & 6.394 & -0.394 & 6.471 & 0.471 \\
\hline 1,2,3,6-teCl & 6.456 & 6.480 & -0.024 & 6.922 & 0.466 \\
\hline 1,2,3,7-teCl & 6.959 & 7.066 & -0.107 & 7.769 & 0.810 \\
\hline 1,2,4,8-teCl & 5.000 & 4.715 & 0.285 & 5.381 & 0.381 \\
\hline $2,3,4,6-\mathrm{teCl}^{\mathrm{b}}$ & 6.456 & 7.321 & -0.865 & 6.991 & 0.535 \\
\hline 2,3,4,7-teCl & 7.602 & 7.496 & 0.106 & 7.917 & 0.315 \\
\hline 2,3,4,8-teCl & 6.699 & 6.976 & -0.277 & 7.266 & 0.567 \\
\hline 2,3,6,8-teCl & 6.658 & 6.008 & 0.650 & 6.224 & 0.434 \\
\hline 2,3,7,8-teCl & 7.387 & 7.139 & 0.248 & 7.774 & 0.387 \\
\hline $1,2,3,4,8-\mathrm{peCl}^{\mathrm{b}}$ & 6.921 & 6.293 & 0.628 & 6.822 & 0.099 \\
\hline 1,2,3,7,8-peCl & 7.128 & 7.213 & -0.085 & 7.598 & 0.470 \\
\hline 1,2,3,7,9-peCl & 6.398 & 5.724 & 0.674 & 6.723 & 0.325 \\
\hline 1,2,4,6,7-peCl & 7.169 & 6.135 & 1.035 & 7.015 & 0.154 \\
\hline 1,2,4,7,8-peCl & 5.886 & 6.607 & -0.720 & 6.136 & 0.250 \\
\hline 1,2,4,7,9-peCl & 4.699 & 4.937 & -0.238 & 5.454 & 0.755 \\
\hline 1,3,4,7,8-peCl & 6.699 & 6.513 & 0.186 & 6.607 & 0.092 \\
\hline
\end{tabular}




\begin{tabular}{llllll}
\hline 2,3,4,7,8-peCl & 7.824 & 7.479 & 0.345 & 8.194 & 0.370 \\
$2,3,4,7,9-\mathrm{peCl}$ & 6.699 & 6.509 & 0.190 & 6.919 & 0.220 \\
$1,2,3,4,7,8-\mathrm{heCl}$ & 6.638 & 6.802 & -0.164 & 7.029 & 0.391 \\
$1,2,3,6,7,8-\mathrm{heCl}^{\mathrm{b}}$ & 6.569 & 7.124 & -0.555 & 7.469 & 0.900 \\
$1,2,4,6,7,8-\mathrm{heCl}$ & 5.081 & 5.672 & -0.591 & 5.648 & 0.567 \\
$2,3,4,6,7,8-\mathrm{heCl}$ & 7.328 & 7.019 & 0.309 & 7.513 & 0.185 \\
Dibenzofuran & 3.000 & 2.765 & 0.235 & 3.422 & 0.422 \\
\hline
\end{tabular}

${ }^{\mathrm{a}}$ AD: the absolute difference

${ }^{\mathrm{b}}$ Compounds for the testing set members

Table S2 Experimental and predicted mutagenic activity $\ln R$ based on our model eq. (2) and Basak et al.' method for the set of 95 aromatic and heteroaromatic amines

\begin{tabular}{|c|c|c|c|c|c|}
\hline \multirow[t]{2}{*}{ Chemicals } & \multirow[t]{2}{*}{ exp. $\ln R^{27}$} & \multicolumn{2}{|c|}{ Basak SC et al. Method ${ }^{17}$} & \multicolumn{2}{|c|}{ This work } \\
\hline & & pred. $\ln R$ & $\mathrm{AD}^{\mathrm{a}}$ & pred. $\ln R$ & $\mathrm{AD}$ \\
\hline 2-Bromo-7-aminofluorene & 2.62 & 1.99 & 0.63 & 2.58 & 0.04 \\
\hline 2-Methoxy-5-methylaniline( $p$-cresidine) & -2.05 & -2.82 & 0.77 & -2.74 & 0.69 \\
\hline 5-Aminoquinoline ${ }^{\mathrm{b}}$ & -2.00 & -1.85 & 0.15 & -1.87 & 0.13 \\
\hline 4-Ethoxyaniline( $p$-phenetidine) & -2.30 & -3.26 & 0.96 & -2.27 & 0.03 \\
\hline 1-Aminonaphthalene ${ }^{\mathrm{b}}$ & -0.60 & -0.61 & 0.01 & -2.01 & 1.41 \\
\hline 4-Aminofluorene & 1.13 & 1.14 & 0.01 & 0.25 & 0.88 \\
\hline 2-Aminoanthracene ${ }^{\mathrm{b}}$ & 2.62 & 1.34 & 1.28 & 1.20 & 1.42 \\
\hline 7-Aminofluoranthene & 2.88 & 3.10 & 0.22 & 2.44 & 0.44 \\
\hline 8-Aminoquinoline & -1.14 & -1.76 & 0.62 & -1.21 & 0.07 \\
\hline 1,7-Diaminophenazine & 0.75 & 0.88 & 0.13 & 1.07 & 0.32 \\
\hline 2-Aminonaphthalene & -0.67 & -0.32 & 0.35 & -1.42 & 0.75 \\
\hline 4-Aminopyrene & 3.16 & 2.57 & 0.59 & 2.91 & 0.25 \\
\hline 3-Amino-3_-nitrobiphenyl b & -0.55 & 0.07 & 0.62 & -0.50 & 0.05 \\
\hline 2,4,5-Trimethylaniline & -1.32 & -1.18 & 0.14 & -1.52 & 0.20 \\
\hline
\end{tabular}




\begin{tabular}{|c|c|c|c|c|c|}
\hline 3-Aminofluorene & 0.89 & 1.25 & 0.36 & 0.80 & 0.09 \\
\hline 3,3_-Dichlorobenzidine ${ }^{\mathrm{b}}$ & 0.81 & -0.17 & 0.98 & 1.12 & 0.31 \\
\hline 2,4-Dimethylaniline(2,4-xylidine) & -2.22 & -2.17 & 0.05 & -2.13 & 0.09 \\
\hline 2,7-Diaminofluorene & 0.48 & 1.11 & 0.63 & 1.91 & 1.43 \\
\hline 3-Aminofluoranthene & 3.31 & 2.65 & 0.66 & 2.86 & 0.45 \\
\hline 2-Aminofluorene & 1.93 & 1.03 & 0.90 & 1.07 & 0.86 \\
\hline 2-Amino-4_-nitrobiphenyl ${ }^{\mathrm{b}}$ & -0.62 & -0.27 & 0.35 & -0.27 & 0.35 \\
\hline 4-Aminobiphenyl & -0.14 & -0.34 & 0.20 & -0.81 & 0.67 \\
\hline 3-Methoxy-4-methylaniline(o-cresidine) & -1.96 & -2.84 & 0.88 & -2.66 & 0.70 \\
\hline 2-Aminocarbazole & 0.60 & 0.69 & 0.09 & 1.19 & 0.59 \\
\hline 2-Amino-5-nitrophenol & -2.52 & -2.86 & 0.34 & -1.63 & 0.89 \\
\hline 2,2_-Diaminobiphenyl ${ }^{\mathrm{b}}$ & -1.52 & -0.15 & 1.37 & -1.08 & 0.44 \\
\hline 2-Hydroxy-7-aminofluorene & 0.41 & 1.13 & 0.72 & 2.09 & 1.68 \\
\hline 1-Aminophenanthrene & 2.38 & 1.19 & 1.19 & 0.93 & 1.45 \\
\hline 2,5-Dimethylaniline & -2.40 & -1.98 & 0.42 & -3.06 & 0.66 \\
\hline 4-Amino-2_-nitrobiphenyl ${ }^{\mathrm{b}}$ & -0.92 & -0.05 & 0.87 & 0.11 & 1.03 \\
\hline 2-Amino-4-methylphenol & -2.10 & -4.05 & 1.95 & -2.12 & 0.02 \\
\hline 2-Aminophenazine ${ }^{\mathrm{b}}$ & 0.55 & 1.54 & 0.99 & 1.17 & 0.62 \\
\hline 4, 4_-Diaminophenyl & 0.31 & -0.62 & 0.93 & 0.27 & 0.04 \\
\hline 2,4-Dinitroaniline & -2.00 & -2.07 & 0.07 & -1.78 & 0.22 \\
\hline 2,4-Diaminoisopropylbenzene & -3.00 & -2.56 & 0.45 & -3.21 & 0.21 \\
\hline 2,4-Difluoroaniline ${ }^{\mathrm{b}}$ & -2.70 & -2.43 & 0.27 & -2.19 & 0.51 \\
\hline 4,4_-Methylenedianiline & -1.60 & -0.96 & 0.64 & -0.44 & 1.16 \\
\hline 3,3_-Dimethylbenzidine ${ }^{\mathrm{b}}$ & 0.01 & 0.28 & 0.27 & 0.72 & 0.71 \\
\hline 2-Aminofluoranthene & 3.23 & 3.27 & 0.04 & 2.83 & 0.40 \\
\hline 2-Amino-3-nitrobiphenyl & -0.89 & -0.64 & 0.25 & -0.44 & 0.45 \\
\hline 1-Aminofluoranthene & 3.35 & 3.00 & 0.35 & 2.36 & 0.99 \\
\hline 4,4_-Ethylenebis(aniline) & -2.15 & -1.10 & 1.05 & -1.87 & 0.28 \\
\hline 4-Chloroaniline ${ }^{\mathrm{b}}$ & -2.52 & -2.60 & 0.08 & -2.74 & 0.22 \\
\hline
\end{tabular}




\begin{tabular}{|c|c|c|c|c|c|}
\hline 2-Aminophenanthrene & 2.46 & 1.45 & 1.01 & 1.55 & 0.91 \\
\hline 4-Fluoroaniline & -3.32 & -3.26 & 0.06 & -3.00 & 0.32 \\
\hline 9-Aminophenanthrene ${ }^{\mathrm{b}}$ & 2.98 & 1.36 & 1.62 & 0.63 & 2.35 \\
\hline 3,3_-Diaminobiphenyl & -1.30 & -1.14 & 0.16 & -0.40 & 0.90 \\
\hline 2-Aminopyrene & 3.50 & 2.69 & 0.81 & 2.92 & 0.58 \\
\hline 2,6-Dichloro-1,4-phenylenediamine & -0.69 & -1.02 & 0.33 & -1.54 & 0.85 \\
\hline 2-Amino-7-acetamidofluorene & 1.18 & 0.37 & 0.81 & 1.20 & 0.02 \\
\hline 2,8-Diaminophenazine ${ }^{\mathrm{b}}$ & 1.12 & 0.77 & 0.35 & 1.57 & 0.45 \\
\hline 6-Aminoquinoline & -2.67 & -1.52 & 1.15 & -0.66 & 2.01 \\
\hline 4-Methoxy-2-methylaniline(m-cresidine) & -3.00 & -2.65 & 0.35 & -2.37 & 0.63 \\
\hline 3-Amino-2_-nitrobiphenyl & -1.30 & -0.38 & 0.92 & -0.55 & 0.75 \\
\hline 2,4_-Diamino-biphenyl ${ }^{\text {b }}$ & -0.92 & -0.72 & 0.20 & -0.18 & 0.74 \\
\hline 1,6-Diaminophenazine & 0.20 & -0.34 & 0.54 & 0.15 & 0.05 \\
\hline 4-Aminophenyldisulfide & -1.03 & 0.91 & 1.94 & -1.29 & 0.26 \\
\hline 2-Bromo-4,6-dinitroaniline & -0.54 & -1.06 & 0.52 & -0.58 & 0.04 \\
\hline 2,4-Diamino-n-butylbenzene & -2.70 & -2.36 & 0.34 & -2.08 & 0.62 \\
\hline 4-Aminophenyl ether ${ }^{\mathrm{b}}$ & -1.14 & -0.45 & 0.69 & -0.11 & 1.03 \\
\hline 2-Aminobiphenyl & -1.49 & -0.27 & 1.22 & -1.30 & 0.19 \\
\hline 1,9-Diaminophenazine & 0.04 & 0.00 & 0.04 & 0.62 & 0.58 \\
\hline 1-Aminofluorene & 0.43 & 1.25 & 0.82 & 0.42 & 0.01 \\
\hline 8-Aminofluoranthene & 3.80 & 3.05 & 0.75 & 3.47 & 0.33 \\
\hline 2-Chloroaniline & -3.00 & -2.43 & 0.57 & -3.14 & 0.14 \\
\hline 2-Amino- $\alpha \alpha \alpha$-trifluorotoluene & -0.80 & -1.88 & 1.08 & -1.96 & 1.16 \\
\hline 2-Amino-1-nitronaphthalene & -1.17 & -0.25 & 0.92 & -1.09 & 0.08 \\
\hline 3-Amino-4_-nitrobiphenyl & 0.69 & 0.43 & 0.26 & -0.59 & 1.28 \\
\hline 4-Bromoaniline ${ }^{\mathrm{b}}$ & -2.70 & -1.48 & 1.22 & -2.19 & 0.51 \\
\hline 2-Amino-4-chlorophenol & -3.00 & -1.57 & 1.43 & -2.43 & 0.57 \\
\hline 3,3_-Dimethoxybenzidine & 0.15 & 1.11 & 0.96 & -0.04 & 0.19 \\
\hline 4-Cyclohexylaniline & -1.24 & -1.75 & 0.51 & -0.99 & 0.25 \\
\hline
\end{tabular}




\begin{tabular}{|c|c|c|c|c|c|}
\hline 4-Phenoxyaniline & 0.38 & -0.72 & 1.10 & 0.01 & 0.37 \\
\hline 4,4_-Methylenebis(o-ethylaniline) ${ }^{\text {b }}$ & -0.99 & -0.78 & 0.21 & -0.67 & 0.32 \\
\hline 2-Amino-7-nitrofluorene & 3.00 & 1.87 & 1.13 & 1.98 & 1.02 \\
\hline Benzidine & -0.39 & 0.20 & 0.59 & -0.21 & 0.18 \\
\hline 1-Amino-4-nitronaphthalene & -1.77 & -0.23 & 1.54 & -1.10 & 0.67 \\
\hline 4-Amino-3_-nitrobiphenyl & 1.02 & 0.45 & 0.57 & -0.23 & 1.25 \\
\hline 4-Amino-4_-nitrobiphenyl ${ }^{\mathrm{b}}$ & 1.04 & -0.80 & 1.84 & 0.19 & 0.85 \\
\hline 1-Aminophenazine & -0.01 & 1.32 & 1.33 & 0.46 & 0.47 \\
\hline 4,4_-Methylenebis(o-fluoroaniline) & 0.23 & 0.28 & 0.05 & -0.64 & 0.87 \\
\hline 4-Chloro-2-nitroaniline & -2.22 & -2.12 & 0.10 & -1.76 & 0.46 \\
\hline 3-Aminoquinoline & -3.14 & -1.26 & 1.88 & -0.66 & 2.48 \\
\hline 3-Aminocarbazole & -0.48 & -0.55 & 0.07 & 0.83 & 1.31 \\
\hline 4-Chloro-1,2-phenylenediamine ${ }^{\text {b }}$ & -0.49 & -2.21 & 1.72 & -2.58 & 2.09 \\
\hline 3-Aminophenanthrene & 3.77 & 1.36 & 2.41 & 1.55 & 2.22 \\
\hline 3,4_-Diaminobiphenyl & 0.20 & -0.46 & 0.66 & -0.15 & 0.35 \\
\hline 1-Aminoanthracene & 1.18 & 1.42 & 0.24 & 0.48 & 0.70 \\
\hline 1-Aminocarbazole & -1.04 & -0.54 & 0.50 & 0.49 & 1.53 \\
\hline 9-Aminoanthracene & 0.87 & 1.08 & 0.21 & 0.64 & 0.23 \\
\hline 4-Aminocarbazole & -1.42 & -0.32 & 1.10 & 0.44 & 1.86 \\
\hline 6-Aminochrysene ${ }^{\mathrm{b}}$ & 1.83 & 3.35 & 1.52 & 3.29 & 1.46 \\
\hline 1-Aminopyrene & 1.43 & 3.72 & 2.29 & 2.79 & 1.36 \\
\hline 4-4_-Methylenebis(o-isopropylaniline) & -1.77 & -0.34 & 1.43 & -1.45 & 0.32 \\
\hline 2,7-Diaminophenazine & 3.97 & 0.87 & 3.10 & 1.64 & 2.33 \\
\hline
\end{tabular}

${ }^{\mathrm{a}} \mathrm{AD}$ : the absolute difference

${ }^{\mathrm{b}}$ Compounds for the testing set members

\section{Example:}

Prediction of the aryl hydrocarbon (AH) receptor binding affinity (described as $\mathrm{pEC}_{50}$ ) of 2-Cl-dibenzofuran is exampled as follows. For this compound, the total number of 
group $N$ is 21 , and molecular weight $M$ is 202.56 .

Firstly, the structure for the 2-Cl-dibenzofuran is drawn and optimized by Gaussian software.

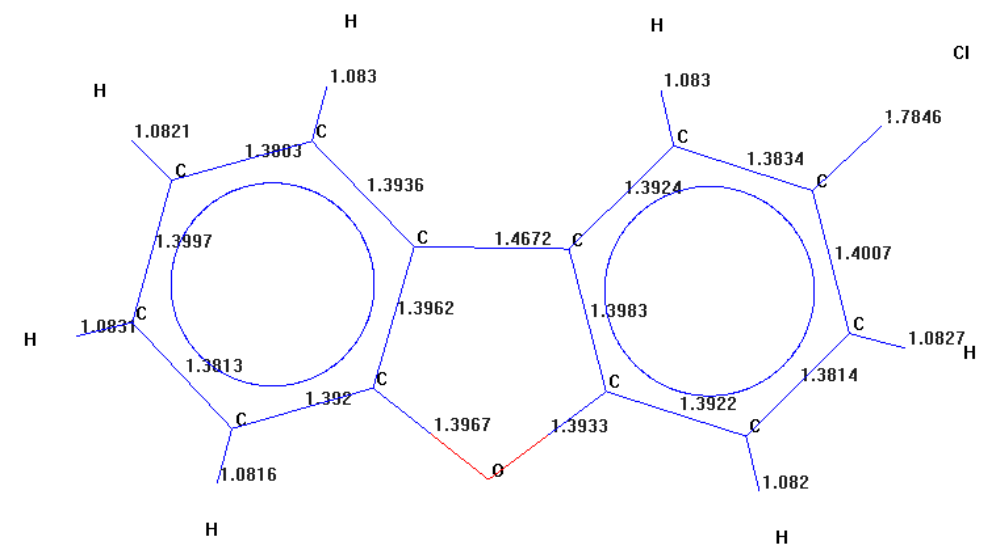

Secondly, the distant matrix $\boldsymbol{M}_{\mathrm{d}}$, and the extended matrix $\boldsymbol{M}_{\mathrm{e}}$ is described as below.

$$
M_{d}=\left[\begin{array}{llllllllllllll}
0 & 1 & 2 & 3 & 2 & 1 & 2 & 3 & 4 & 5 & 4 & 3 & 3 & 2 \\
1 & 0 & 1 & 2 & 3 & 2 & 3 & 4 & 5 & 6 & 5 & 4 & 4 & 1 \\
2 & 1 & 0 & 1 & 2 & 3 & 4 & 4 & 5 & 6 & 6 & 5 & 3 & 2 \\
3 & 2 & 1 & 0 & 1 & 2 & 3 & 3 & 4 & 5 & 5 & 4 & 2 & 3 \\
2 & 3 & 2 & 1 & 0 & 1 & 2 & 2 & 3 & 4 & 4 & 3 & 1 & 4 \\
1 & 2 & 3 & 2 & 1 & 0 & 1 & 2 & 3 & 4 & 3 & 2 & 2 & 3 \\
2 & 3 & 4 & 3 & 2 & 1 & 0 & 1 & 2 & 3 & 2 & 1 & 2 & 4 \\
3 & 4 & 4 & 3 & 2 & 2 & 1 & 0 & 1 & 2 & 3 & 2 & 1 & 5 \\
4 & 5 & 5 & 4 & 3 & 3 & 2 & 1 & 0 & 1 & 2 & 3 & 2 & 6 \\
5 & 6 & 6 & 5 & 4 & 4 & 3 & 2 & 1 & 0 & 1 & 2 & 3 & 7 \\
4 & 5 & 6 & 5 & 4 & 3 & 2 & 3 & 2 & 1 & 0 & 1 & 4 & 6 \\
3 & 4 & 5 & 4 & 3 & 2 & 1 & 2 & 3 & 2 & 1 & 0 & 3 & 5 \\
3 & 4 & 3 & 2 & 1 & 2 & 2 & 1 & 2 & 3 & 4 & 3 & 0 & 5 \\
2 & 1 & 2 & 3 & 4 & 3 & 4 & 5 & 6 & 7 & 6 & 5 & 5 & 0
\end{array}\right]
$$

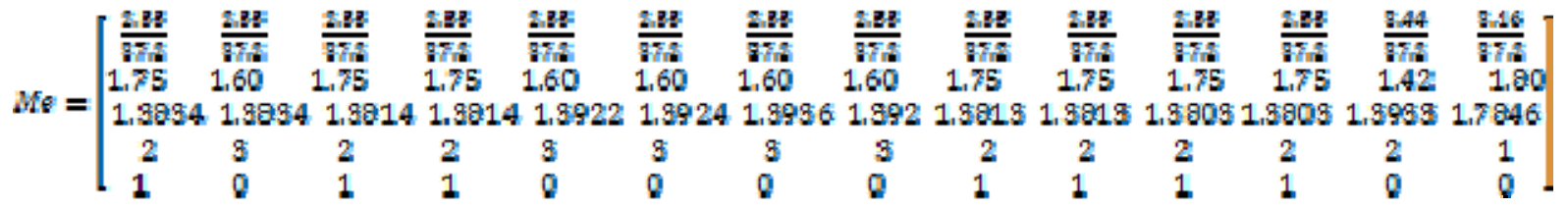

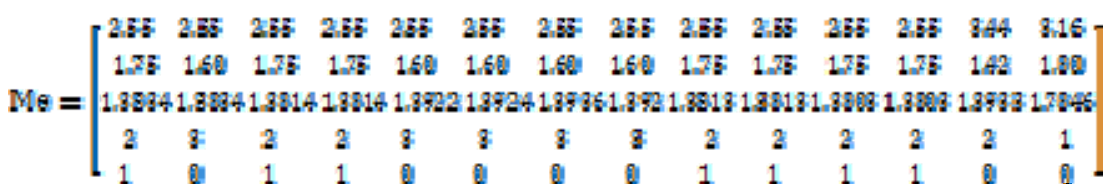


Thirdly, in this work, the norm values of the extended matrix are calculated and shown as in Table S3.

Table S3 Norm values of extended matrix for 2-Cl-dibenzofuran

\begin{tabular}{ccccc}
\hline extended matrix & norm(M,1) & norm(M,2) & norm(M,fro) & norm(M,inf) \\
\hline $\mathrm{M}_{\mathrm{D}}$ & 57.6696 & 41.6355 & 46.7410 & 53 \\
$\mathrm{M}_{\mathrm{A}}$ & 9.0621 & 12.3061 & 13.5912 & 32 \\
$\mathrm{M}_{\mathrm{B}}$ & 11.06215 & 12.5624 & 14.0968 & \\
$\mathrm{M}_{\mathrm{C}}$ & 10.2020 & 12.4590 & 13.9542 & \\
\hline
\end{tabular}

Lastly, from parameters in Table 3, the $\mathrm{pEC}_{50}$ of 2-Cl-dibenzofuran is predicted by Eq.

(1):

$$
\begin{aligned}
p E C_{50}= & 0.2730 \times 57.6696-18.5465 \times 41.6355+14.0124 \times 46.7410-0.1447 \times 53-22.7744 \times 9.0621 \\
& -48.5409 \times 12.3061-462.3183 \times 13.5912-5.9163 \times 32-0.1887 \times 11.0625 \\
& +156.6532 \times 12.5624+428.6100 \times 14.0970+0.2801 \times 10.2020-55.6900 \times 12.4590 \\
& +16.3321 \times 13.9542+3544.4709 \exp \left(\frac{1}{21}\right)+10679.1349 \exp \left(\frac{1}{202.56}\right)-14604.7935 \\
= & 3.665
\end{aligned}
$$

The calculated result is 3.665 while the experimental $\mathrm{pEC}_{50}$ is 3.553 . 